\title{
Well recognised but still overlooked: norepinephrine extravasation
}

\author{
Sun Moon Kim, ${ }^{1}$ Shamik Aikat, ${ }^{2}$ Alison Bailey ${ }^{2}$ \\ ${ }^{1}$ Department of Internal Medicine, University of Kentucky, Lexington, Kentucky, USA \\ ${ }^{2}$ Department of Cardiovascular Medicine, University of Kentucky, Gill Heart Institute, Lexington, Kentucky, USA
}

Correspondence to Dr Sun Moon Kim, sunmoon.kim@uky.edu

\section{DESCRIPTION}

A 46-year-old man was transferred from an outside hospital for evaluation of acute renal failure and non-ST-segment elevation myocardial infarction. During his initial presentation at the outside hospital, the patient was profoundly hypotensive with signs of respiratory failure. Owing to the perceived urgency, he was started on norepinephrine for haemodynamic support through a peripheral intravenous line. Following the resolution of haemodynamic instability, the patient was noted to have a large subcutaneous lesion on his right forearm around his peripheral intravenous site. The lesion consisted of a large serous bullae and exhibited marked pallor, coldness and mottling of the skin. The patient underwent mechanical debridement of the necrotic tissue and was treated with topical silver sulfadiazine.

Norepinephrine is an a-adrenergic agonist commonly used for the treatment of shock. A well-known side effect of norepinephrine is the potential for subcutaneous tissue ischaemia in the event of inadvertent extravasation. When extravasation from a peripheral cannula occurs, the relatively high concentration of epinephrine in both the

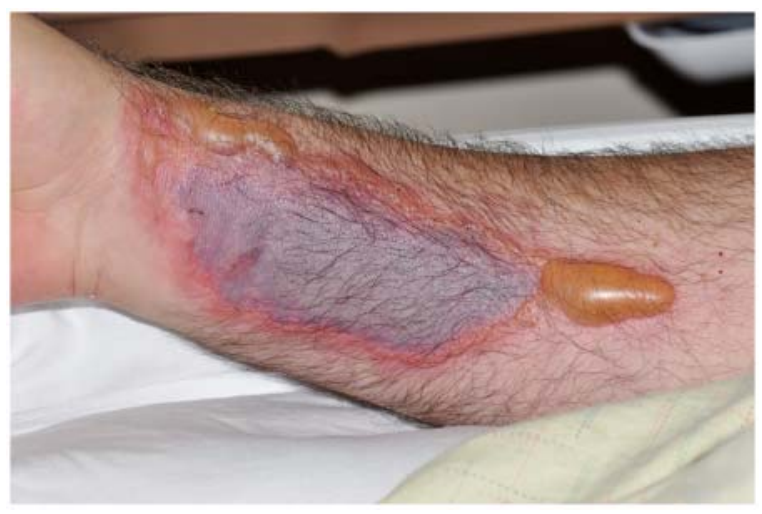

Figure 1 Subcutaneous tissue ischaemia of right forearm following extravasation of norepinephrine during peripheral intravenous infusion. recipient vein and adjacent blood vessels induce subcutaneous tissue ischaemia through marked vasoconstriction and increased vascular permeability (figure 1). ${ }^{1-3}$ Cases of skin necrosis with peripheral infusions continue to be seen despite longstanding awareness that vasopressors need to be administered through a central venous catheter for rapid dilution. ${ }^{2}$ Treatment of extravasation injuries includes prompt discontinuation of the peripheral intravenous infusion, and the administration of a pharmacological vasodilator such as phentolamine, an a-adrenergic antagonist. ${ }^{3}$ Should subcutaneous necrosis occur, general wound care measures such as mechanical debridement are recommended.

\section{Learning points}

- Skin necrosis with subcutaneous extravasation of vasopressors continues to occur despite widespread knowledge of need to avoid peripheral venous administration.

- The pathophysiology involves the relatively high concentration of norepinephrine in both the recipient vein and adjacent blood vessels leading to vasoconstriction and increased vascular permeability.

- Treatment following the extravasation includes discontinuation of the intravenous site, pharmacological vasodilators and wound care.

Competing interests None.

Patient consent Obtained.

\section{REFERENCES}

1. Weeks PM. Ischemia of the hand secondary to levarterenol bitartrate extravasation. Methods of management. JAMA 1966;196:288-90.

2. Humphreys J, Johnston JH, Richardson JC. Skin necrosis following intravenous noradrenaline. Br Med J 1955;2:1250-2.

3. Oglesby JE, Baugh JH. Tissue necrosis due to norepinephrine. Am J Surg 1968;115:408-12. 


\section{BMJ Case Reports}

This pdf has been created automatically from the final edited text and images.

Copyright 2012 BMJ Publishing Group. All rights reserved. For permission to reuse any of this content visit http://group.bmj.com/group/rights-licensing/permissions.

BMJ Case Report Fellows may re-use this article for personal use and teaching without any further permission.

Please cite this article as follows (you will need to access the article online to obtain the date of publication).

Kim SM, Aikat $S$, Bailey A. Well recognised but still overlooked: norepinephrine extravasation.

BMJ Case Reports 2012;10.1136/bcr-2012-006836, Published XXX

Become a Fellow of BMJ Case Reports today and you can:

- Submit as many cases as you like

- Enjoy fast sympathetic peer review and rapid publication of accepted articles

- Access all the published articles

- Re-use any of the published material for personal use and teaching without further permission

For information on Institutional Fellowships contact consortiasales@bmjgroup.com

Visit casereports.bmj.com for more articles like this and to become a Fellow 